\title{
Permselectivity of blood follicle barriers in mouse ovaries of the mifepristone-induced polycystic ovary model revealed by in vivo cryotechnique
}

\author{
Hong Zhou $^{1,2}$, Nobuhiko Ohno ${ }^{1}$, Nobuo Terada ${ }^{1}$, Sei Saitoh ${ }^{1}$, Ichiro Naito ${ }^{3}$ and Shinichi Ohno ${ }^{1}$ \\ ${ }^{1}$ Department of Anatomy and Molecular Histology, Interdisciplinary Graduate School of Medicine and Engineering, \\ University of Yamanashi, 1110 Shimokato, Chuo-City, Yamanashi 409-3898, Japan, ${ }^{2}$ Department of Child, Adolescent \\ and Women's Health, School of Public Health, Peking University, Beijing 100083, China and ${ }^{3}$ Department of Human \\ Morphology, Okayama University Graduate School of Medicine, Dentistry and Pharmaceutical Sciences, Shikata, \\ Okayama 700-8558, Japan
}

Correspondence should be addressed to S Ohno; Email: sohno@yamanashi.ac.jp

\begin{abstract}
Despite the potential association of polycystic ovary (PCO) syndrome with hemodynamic changes, follicular microenvironment and the involvement of blood follicle barriers (BFB), a histopathological examination has been hampered by artifacts caused by conventional preparation methods. In this study, mouse ovaries of a mifepristone-induced PCO model were morphologically and immunohistochemically examined by in vivo cryotechnique (IVCT), which prevents those technical artifacts. Ovarian specimens of PCO model mice were prepared by IVCT or the conventional perfusion fixation after s.c. injection of mifepristone. Their histology and immunolocalization of plasma proteins, including albumin (molecular mass, $69 \mathrm{kDa}$ ), immunoglobulin $\mathrm{G}$ (IgG, $150 \mathrm{kDa}$ ), inter- $\alpha$-trypsin inhibitor (ITI, $220 \mathrm{kDa})$, fibrinogen $(340 \mathrm{kDa})$, and $\operatorname{IgM}(900 \mathrm{kDa})$, were examined. In the PCO model, enlarged blood vessels with abundant blood flow were observed in addition to cystic follicles with degenerative membrana granulosa. The immunolocalization of albumin and IgM in the PCO model were similar to those in normal mice. Albumin immunolocalized in the blood vessels, interstitium or follicles, and IgM was mostly restricted within the blood vessels. In contrast, immunolocalization of IgG, ITI, and fibrinogen changed in the PCO model. Both IgG and ITI were clearly blocked by follicular basement membranes, and hardly observed in the membrana granulosa, though fibrinogen was mostly observed within blood vessels. These findings suggest that increased blood flow and enhanced selectivity of molecular permeation through the BFB are prominent features in the PCO ovaries, and changes in hemodynamic conditions and permselectivity of BFB are involved in the pathogenesis and pathophysiology of PCO syndrome.
\end{abstract}

Reproduction (2008) 136 599-610

\section{Introduction}

Polycystic ovary (PCO) syndrome is an important cause of anovulation and a common disorder in reproductiveage women (Franks 1995, Knochenhauer et al. 1998). There is a prominent diversity of clinical symptoms and histological features in the PCO syndrome. It is well established that menstrual irregularity, hyperandrogenism, hirsutism, chronic anovulation, infertility, and obesity are associated with PCO. In addition, most patients are found to have histopathological findings such as multiple cystic follicles with large volume, thecal cell hyperplasia, and degenerative changes in the granulosa of follicles (Franks 1995, Legro 2001, Ehrmann 2005). In PCO syndrome, there is also evidence indicating the arrest of follicular maturation, and the function of ovarian follicles is suspended at an early follicular phase of development (Franks 1989). Although the precise mechanisms, inducing the arrest of follicular maturation in PCO syndrome, have not been elucidated, changes in follicular morphology in the PCO syndrome could be partly attributable to differences in the follicular microenvironment. Some changes of the components in follicular fluids have been reported in PCO syndrome patients, including insulin-like growth factor binding proteins, inhibins A and B and death factor Fas ligand (San Roman \& Magoffin 1992, Onalan et al. 2005, Welt et al. 2005). The follicular fluid, which contributes to the follicular microenvironment by containing some necessary endocrine and non-endocrine growth factors within the avascular compartment of follicles, is usually produced not only by secretion from granulosa cells but also by plasma protein diffusion from thecal capillaries during follicular development (Donahue \& Stern 1968, Gosden et al. 1988, Gull et al. 1999, Angelucci et al. 2006). Several earlier studies already 
described definite differences in both protein composition and concentrations between the follicular fluid and the blood plasma, which led to a proposal of the blood follicle barrier (BFB; Zachariae 1958, Shalgi et al. 1973). The BFB had been described as a 'molecular sieve' with charge and size selectivity occurring in the capillary endothelium, the theca interna, the basement membrane, and the membrana granulosa. In previous studies, the BFB under physiological conditions was found to allow low and intermediate molecular mass proteins such as albumin $(69 \mathrm{kDa})$ and immunoglobulin G1 (IgG1; $150 \mathrm{kDa}$ ) to enter the follicular fluid, but block the entrance of higher molecular components or larger particles, such as IgM (900 kDa; Shalgi et al. 1973, Cran et al. 1976, Zhou et al. 2007 b). In addition, the follicular basement membrane and the vascular endothelium play significant roles in the permselectivity, the selectivity of molecular permeation, for some soluble plasma proteins (Powers et al. 1995, Zhou et al. 2007b). These previous studies indicate that ovarian histology and the follicular microenvironment could be significantly changed in PCO syndrome and that the BFB could be involved in the functional changes through modulation of the components in follicular fluid. However, the knowledge about such changes in ovarian histology and BFB in the PCO syndrome are still limited, because conventional chemical fixation and dehydration often produces various morphological artifacts and molecular translocation caused by anoxia of tissue resection, artificial perfusion pressures with fixatives and dehydration shrinkage with organic solvents (Kellenberger 1991, Hippe-Sanwald 1993, Shiurba 2001, Li et al. 2006, Zhou et al. 2007a, 2007b).

The present study morphologically and immunohistochemically examined the ovaries of living PCO model mice using in vivo cryotechnique (IVCT) to reveal the functional morphology of ovaries in PCO and the potential association with BFB. One of the PCO models, which is induced by mifepristone and considered in rats to be a PCO syndrome model 'fundamentally adequate' to investigate the effect of PCO syndrome-like endocrinological perturbations on ovarian physiology and histology during the short term of 1-2 weeks, was used (Ruiz et al. 1996, Lakhani et al. 2006). The IVCT is a kind of cryofixation method, in which the target organs of living animals are directly frozen in vivo without tissue resection or perfusion fixation, and enables the capture of transient changes in tissue and cell morphology without the artifacts inevitable by the conventional tissue preparation methods. In addition, the IVCT retains soluble extra- and intracellular molecules very efficiently within tissues and cells, and histologically or immunohistochemically reveals clear localization or dynamic changes in the functional molecules in vivo on the prepared sections (Zea-Aragon et al. 2004, Terada et al. 2005, Li et al. 2006, Liao et al. 2006, Ohno et al. 2006).

\section{Results}

\section{Histological examination of mouse ovaries after injection of mifepristone}

The estrous cycles of all mice were checked daily by vaginal smear examination from the first day of mifepristone injection. Following 2-4 days of injection of mifepristone, the normal estrous cycles were disturbed to be 'persistent vaginal cornification' or consecutive estrous stage until the time of tissue fixation (Ruiz et al. 1996). The persistent vaginal smear was consistent with the findings of previous report using the oral administration of mifepristone (Gao \& Short 1994). After the ovarian tissue specimens were prepared with perfusion fixation and alcohol dehydration (PF-DH) and also IVCT, the paraffin sections from control or mifepristone-induced PCO model mice were first examined following hematoxylin-eosin (HE) staining (Fig. 1). Typical follicular cysts could be found in the specimens from mifepristone-induced PCO model mice (Fig. 1b), although various kinds of developing follicles were observed in the specimens of control mice prepared by PF-DH (Fig. 1a). At higher magnification, a decreased thickness of the degenerative membrana granulosa was found in the PCO model mice (Fig. 1d), although large antral follicles with multilayered granulosa cells could be observed in the control mice (Fig. 1c). In addition to the histological findings obtained with PF-DH, more widely open blood vessels with flowing erythrocytes were clearly observed in both the cortex and medulla areas of the mifepristone-induced PCO model mice, prepared by IVCT (Fig. 1f), in comparison with the control mice (Fig. 1e). At higher magnification, both the numbers and volume of blood vessels in the theca interna and medulla of ovaries appeared to be increased in the PCO model (Fig. 1g and h). The histological changes following mifepristone administration were quantitatively examined using IVCT. In the PCO model mice, the number of antral follicles on ovarian sections significantly increased (Fig. 1i), and also the granulosa cell layer compared with the thecal layer was thinner (Fig. 1j).

To confirm the histological findings of blood vessels, the volume of blood vessels in the ovaries of control and PCO model mice was statistically compared on the HE-stained sections using the modified Chalkley method, because there was prominent diversity of vascularity in the ovaries of the PCO model, in comparison with the controls (Fig. 2). The modified Chalkley method, which estimates relative volume of certain structures, was used to compare the volume of blood or lymphatic vessels in neoplastic tissues (Chalkley 1943, Curtis 1960, Williams et al. 2003, Hansen et al. 2004). The Chalkley count representing vascular volume was significantly higher in the medulla areas of the PCO model mice than those in the control mice (Fig. $2 \mathrm{~g}, P<0.05$ ). The vascular diameters in the theca interna were also compared by measuring the length of the shortest axis of each blood vessel profiles (Fig. 2e and f), and the vascular diameters were 

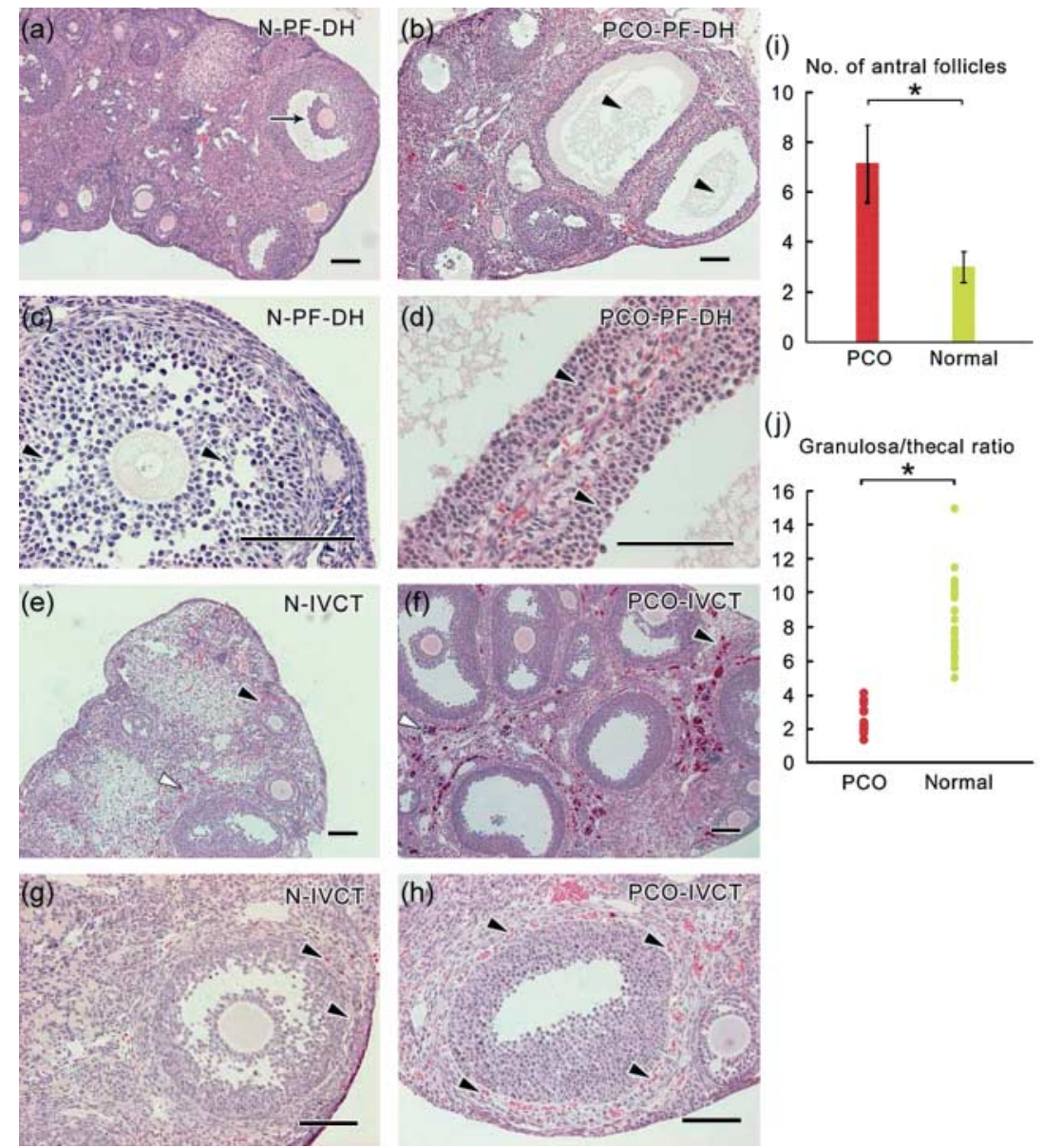

Figure 1 Light micrographs of hematoxylin-eosin staining on paraffin sections from control (N; a, c, e, g) or polycystic ovary model (PCO; b, d, f, h) mice prepared by perfusion fixation followed by alcohol dehydration (PF-DH; a-d) or in vivo cryotechnique (IVCT, e-h). (a and b) In the specimens of PCO mice, typical follicular cysts can be seen (b, arrowheads), although various stages of developing follicles are observed, including antral follicles (a, arrow), in the specimens of control mice prepared by PF-DH. (c and d) At higher magnification, in comparison with the large antral follicles with multilayered cell population in the specimens of control mice prepared by PF-DH (c, arrowheads), degenerative membrana granulosa are seen in the specimens of PCO mice ( $d$, arrowheads). (e and f) In addition to the findings obtained with PF-DH, the open blood vessels in the ovaries are well preserved in the specimens prepared by IVCT. In comparison with ovaries in the living control mice (e, arrowhead, white arrowhead), many open blood vessels with flowing erythrocytes are observed in both the cortex (f, arrowheads) and medulla (f, white arrowheads) of PCO ovaries. (g and h) At higher magnification, not only the numbers but also the volume of blood vessels in both the theca interna and medulla of ovaries appear to be increased in the specimens prepared by IVCT (h, arrowheads), in comparison with the ovaries in the living control mice ( $\mathrm{g}$, arrowheads). Bars,

$100 \mu \mathrm{m}$. (i) The number of antral follicles observed on single sections of PCO model (PCO) or normal ovaries. A significantly larger number of the follicles can be observed in the PCO model $\left({ }^{*} P<0.05\right) . N=20$. Mean (thick bars) \pm s.D. (thin bars) are $7.2 \pm 1.5$ for PCO and $3.0 \pm 0.6$ for normal mice. (j) Graph showing the ratio of granulosa cell layer thickness and thecal layer thickness. Note that the thickness of the granulosa cell layer significantly decreased in the PCO model in comparison with the thecal layer. $N=20 .{ }^{*} P<0.05$.

significantly larger in the PCO model mice than in the control mice (Fig. $2 \mathrm{~h}, P<0.05$ ). These results suggest that in addition to the formation of follicular cysts, increases in vascularity and blood circulation are characteristic features of PCO syndrome, and such dynamic changes could be precisely captured with the IVCT.

\section{Immunohistochemical examination of BFB in PCO model mice}

Next, serial paraffin sections of either the control (Fig. 3a-d, i-k, o-q, u-w) or PCO model mice (Fig. 3e-h, I-n, r-t, $x-z$ ), which were all prepared with
IVCT, were stained with HE or immunostained for three plasma proteins, albumin (molecular mass $69 \mathrm{kDa}$ ), IgG1 (150 kDa) and IgM (900 kDa). In the antral follicles of both the control and PCO mice, all three proteins were clearly immunolocalized in open blood vessels (Fig. 3). The immunoreactivity of albumin was clearly detected in the antral follicles of the PCO model mice (Fig. 3f, $m$ and $n$ ), and similar to that of the control mice (Fig. $3 \mathrm{~b}, \mathrm{j}$ and $\mathrm{k}$ ), which are consistent with the findings reported previously (Zhou et al. 2007b). Some weak immunoreactivity of $\operatorname{lgG} 1$ was seen in the membrana granulosa and antrum of the follicles compared with the thecal layers and blood vessels in the control mice 

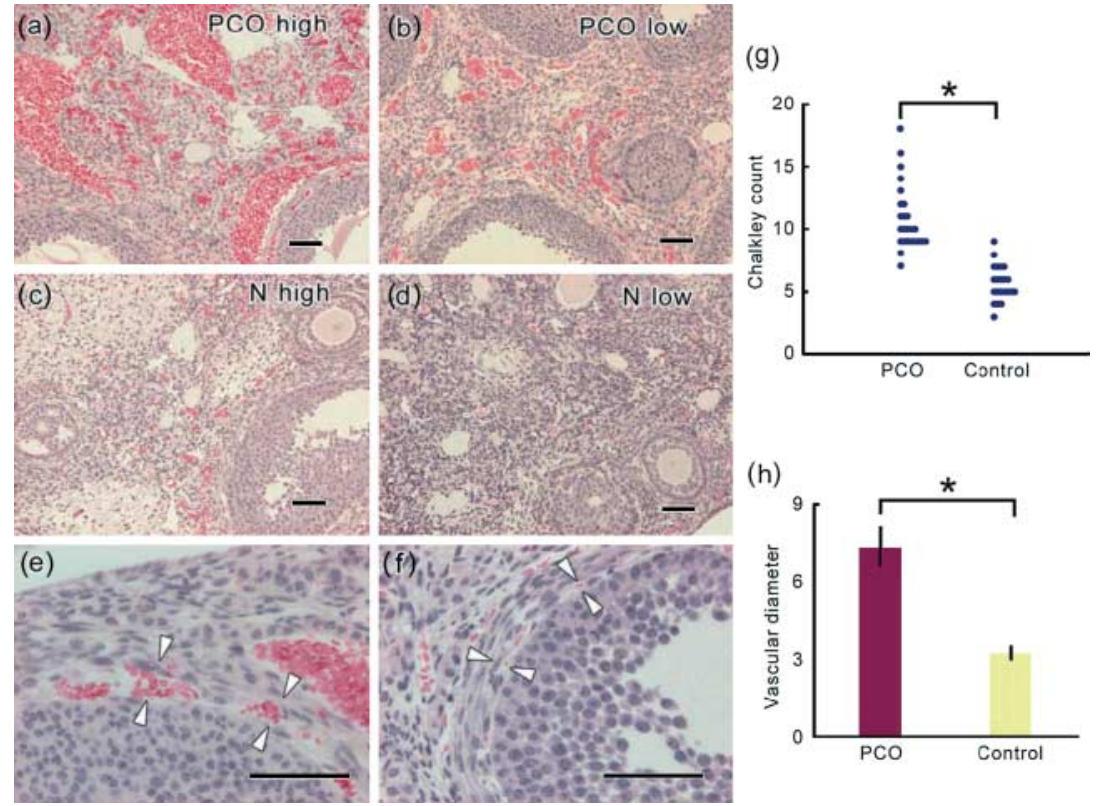

Figure 2 (a-f) Light micrographs of hematoxylin-eosin staining on paraffin sections from polycystic ovary model (PCO; a, b, e) or control mice $(\mathrm{N} ; \mathrm{c}, \mathrm{d}, \mathrm{f})$ prepared by in vivo cryotechnique. High $(\mathrm{a}, \mathrm{c})$ or low $(\mathrm{b}, \mathrm{d})$ densities of vasculature can be observed on the paraffin sections. Note that there is a prominent diversity of the number and volume of vascularity in the PCO ovaries (a, b), in comparison with the normal ones (c, d). At higher magnification, the size of blood vessels in the theca interna appears to be larger in the PCO than in the control mice (e, f, white arrowheads). (g) Relative comparison of vascular volume in the medulla between the PCO and control mice, as estimated with the modified Chalkley method. The Chalkley count representing vascular volume is significantly higher in the PCO than in the control mice $(g, * P<0.05, N=25)$. (h) Comparison of vascular diameters in thecal layers between the PCO and control mice. The mean of vascular diameter in the shorter axis is significantly larger in the PCO mice than that in the control mice $(h, * P<0.05)$. Means (thick bars) \pm s.D. (thin bars) are $7.3 \pm 0.8 \mu \mathrm{m}$ for PCO and $3.2 \pm 0.3 \mu \mathrm{m}$ for control mice. Bars, $50 \mu \mathrm{m}$.

(Fig. 3c, p and q), as also reported previously (Zhou et al. 2007b). In contrast, little immunoreactivity of IgG1 could be seen in the membrana granulosa of PCO model ovaries (Fig. 3g and s), although there was some weak immunoreactivity in the antrum (Fig. $3 g$ and $\mathrm{t}$ ). Furthermore, immunostaining for IgM in the PCO model mice was similar to that in control mice; the immunoreactivity of IgM was decreased in the interstitium and thecal layers in their ovaries (Fig. 3d, h, $u$ and $\mathrm{x})$, although it was strongly observed inside the blood vessels of the thecal layers in the PCO model mice (Fig. 3h). The immunostaining for IgM was hardly seen inside the follicles in both the PCO model and control mice (Fig. 3d, h, v, w, y and z). In immunocontrol sections, no immunostaining was observed (Fig. 4). To confirm these findings, semi-quantitative analyses of IgG immunoreactivity in different areas of the ovaries was performed in the PCO model and normal mice (Table 1). Although a strong immunoreactivity of IgG1 could be observed in the blood vessels of both the PCO model and normal mice, the immunoreactivity was significantly diminished in the granulosa cell layer of the PCO model mice. However, it was not significantly different in antrum. These findings suggested that the albumin in the PCO model mice can easily enter into the ovarian follicles, but IgM was blocked around the blood vessels, as previously reported in normal mice (Zhou et al.
$2007 b$ ). On the other hand, a lower amount of components with intermediate molecular weights, such as IgG, was observed to be able to enter the ovarian follicles of the PCO model mice, in comparison with those of the normal mice.

To further examine the distribution of IgG and other molecules with intermediate molecular weights, which already exhibited the similar immunolocalization to $\lg \mathrm{G}$ in normal mice under normal physiological conditions (Zhou et al. 2007 b), cryosections of the PCO model mice prepared with IVCT were used for double immunofluorescence labeling of collagen type IV, a marker for follicular and vascular basement membranes, and some plasma proteins including IgGfc $(150 \mathrm{kDa})$, inter- $\alpha$ trypsin inhibitor (ITI, $220 \mathrm{kDa})$, or fibrinogen (340 kDa; Fig. 5). The immunoreactivity of IgGfc inside the antral follicles of the PCO model mice was similar to that observed by the immunoperoxidase staining (Fig. 5a-d), as shown in Fig. 3g. Little immunoreactivity of IgGfc was seen in the membrana granulosa in the antral follicles, in comparison with the thecal layers and blood vessels, but some immunoreactivity was detected around the antrum in the PCO model mice (Fig. $5 \mathrm{a}$ and d). The prominent decrease in IgGfC immunoreactivity was clearly bordered at the follicular basement membranes immunopositive for collagen type IV (Fig. $5 b$ and d). Almost no immunoreactivity of ITI was seen in the membrana 

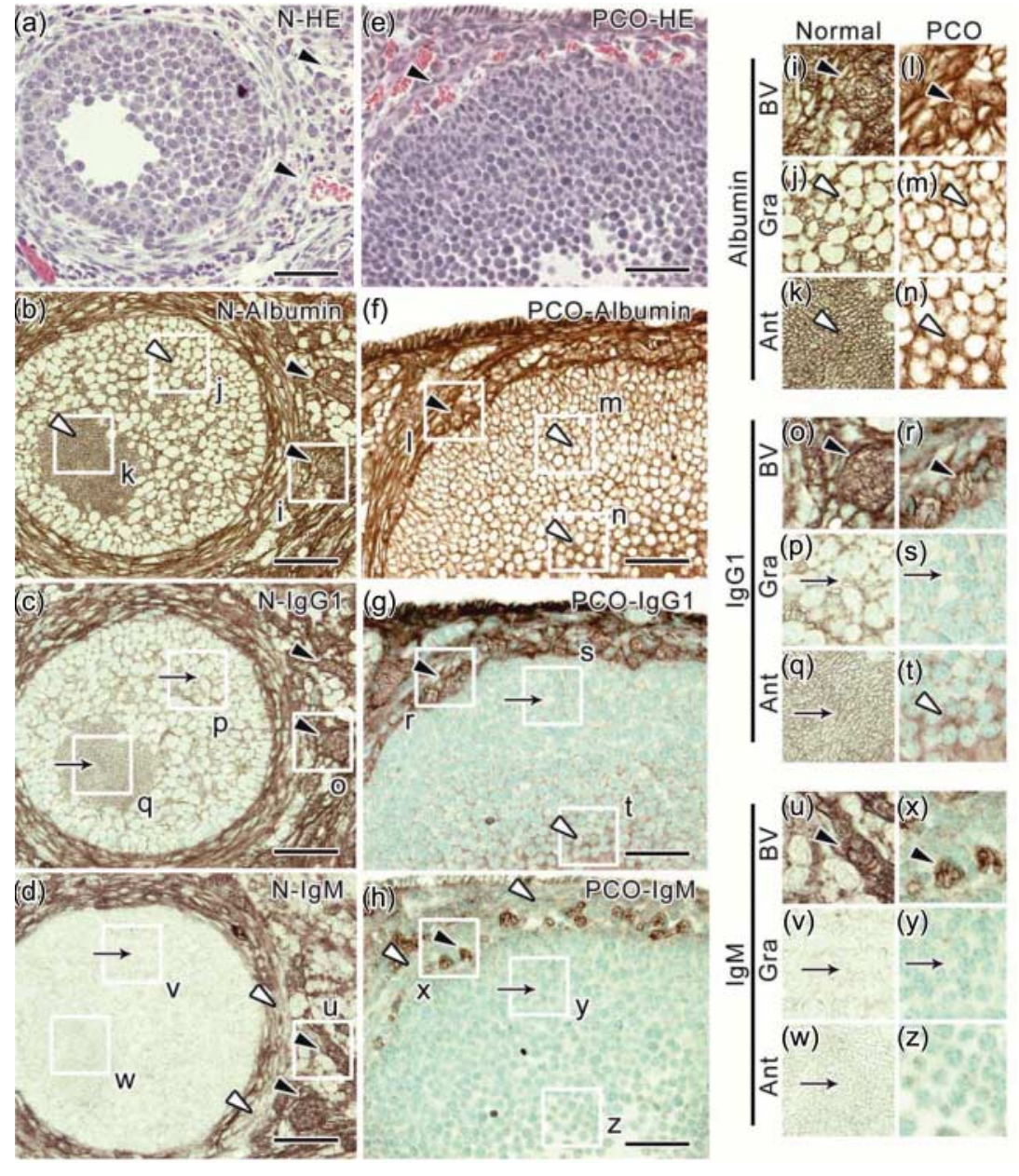

Figure 3 Light micrographs of antral follicles in the control (N; a-d, i-k, o-q, u-w) or mifepristoneinduced polycystic ovary model (PCO; e- $\mathrm{h}, \mathrm{I}-\mathrm{n}$, $r-t, x-z)$ mice on serial paraffin sections, prepared by in vivo cryotechnique, and stained with hematoxylin-eosin ( $\mathrm{HE}, \mathrm{a}, \mathrm{e})$ or immunostained for albumin (b, f, i-n), immunoglobulin G (IgG1, c, g, $\mathrm{o}-\mathrm{t})$ or $\lg \mathrm{M}(\mathrm{d}, \mathrm{h}, \mathrm{u}-\mathrm{z})$. The areas marked with white rectangles and alphabets in b- $\mathrm{d}$ and $\mathrm{f}-\mathrm{h}$ are shown in $(\mathrm{i}-\mathrm{z})$ at higher magnification. The strong immunoreactivity of the three plasma proteins is detected inside the blood vessels (BV; $a-h, i, l, o, r$, $\mathrm{u}, \mathrm{x}$, black arrowheads) of both control and PCO mice. The immunoreactivity of albumin can be more clearly detected in membrana granulosa (Gra) and antrum (Ant; b, f, j, k, m, n, white arrowheads). Some immunoreactivity of IgG1 is seen in the membrana granulosa of the follicles in control mice (c, p, q, arrows), although it is weaker than that in thecal layers and blood vessels. In contrast, little immunoreactivity of $\lg \mathrm{G} 1$ ( $\mathrm{g}$, s, arrows) can be seen in the granulosa cell layer of PCO ovaries, but its immunoreactivity is slightly observed in antrum ( $\mathrm{g}$, $\mathrm{t}$, white arrowheads). The immunoreactivity for IgM is decreased in the interstitium ( $d$, h, white arrowheads), in comparison with that in the blood vessels $(\mathrm{d}, \mathrm{h}, \mathrm{u}, \mathrm{x}$, black arrowheads), and hardly seen in the follicles of both control and PCO mice (d, h, v, w, y, arrows). Bars, $40 \mu \mathrm{m}$. granulosa in the antral follicles, in comparison with both the thecal layers and blood vessels, although there was slight immunoreactivity in the antrum of the PCO model mice (Fig. 5e and h). The immunolocalization of ITI in the theca interna appeared to be bordered by collagen type IV-immunopositive follicular basement membranes in the PCO model mice, as seen with IgGfC (Fig. $5 f$ and h). The immunoreactivity of fibrinogen was hardly detected inside the antral follicles in the PCO model mice and very weakly in the thecal interstitium, but it was clearly seen in the blood vessels of the thecal layers (Fig. $5 \mathrm{i}$ and I). When compared with the immunostaining for collagen type IV, the immunolocalization of fibrinogen was mostly restricted in the blood vessels surrounded by the collagen type IV-immunopositive basement membranes, and also partly separated by the follicular basement membranes (Fig. $5 \mathrm{j}$ and I).

Since the immunoreactivity of IgGfC and ITI in the thecal interstitium was bordered by the follicular basement membranes, which are shown in Fig. 5, some collagen type IV $\alpha$-chains were immunohistochemically examined to reveal any changes in the major components of the basement membranes (Rodgers et al. 1998, Nakano et al. 2007). However, no apparent differences in the collagen $\alpha$-chains were observed in the antral follicles between the PCO model and control mice (Fig. 6). The $\alpha 2$-chain was immunolocalized in most basement membranes around the ovarian follicles and blood vessels in both the PCO model and control mice. Immunoreactivity of the $\alpha 4$-chain was detected only at the follicular basement membranes of primordial follicles. The a5-chain was clearly immunolocalized at the basement membranes of primordial follicles and another germinal epithelium, and weakly at the basement membrane and thecal interstitium of antral follicles.

\section{Discussion}

In the present study, the s.c. injection of the antiprogestin mifepristone was used to produce a PCO model in mice. Some previous studies have reported the estrous cycle and ovulation to be stopped by the administration of RU486 in mice as observed in the present study (Loutradis et al. 1991, Gao \& Short 1994), and the anovulation and PCO have been included in the diagnostic criteria of PCO syndrome (The Rotterdam ESHRE/ASRM-Sponsored PCOS Consensus Workshop Group 2004). During 


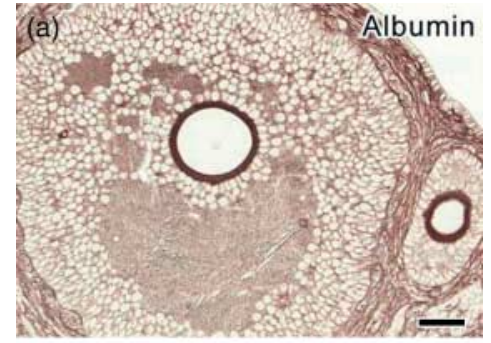

(b)
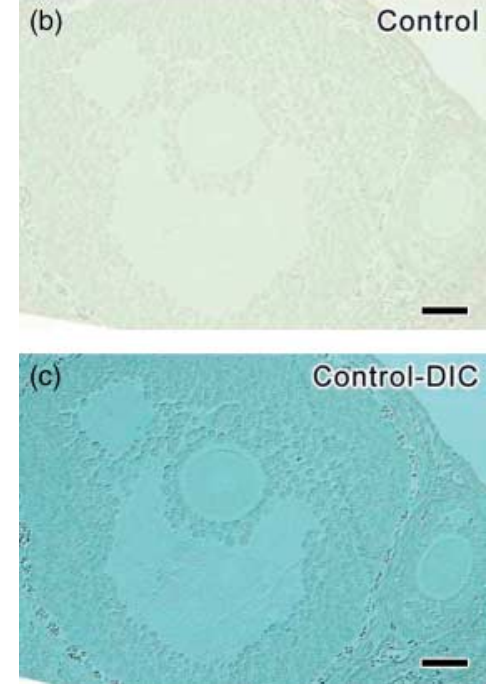

Figure 4 Light micrographs of antral follicles in the mifepristoneinduced polycystic ovary model mice on serial paraffin sections prepared by in vivo cryotechnique. The immunoreactivity of albumin (a) is eliminated in the immunocontrol section (b). A differential interference contrast (DIC) image of the immunocontrol section is also shown (c). Bars: $40 \mu \mathrm{m}$.

the past few decades, some researchers have used such animal models as rats, mice, hamsters, guinea pigs, and subhuman primates to study the pathophysiology of chronic anovulation in PCO syndrome (Singh 2005). As a result, since the 1960s, various PCO syndrome models, including estradiol valerate, DHEA, or an androgenized animal model, have been developed, although a fully convincing model of human PCO syndrome has not been established (Mahesh et al. 1987, Mahajan 1988, Szukiewicz \& Uilenbroek 1998, Singh 2005). However, the administration of mifepristone to rats was recently used as a good model of human PCO syndrome (Singh 2005, Lakhani et al. 2006). The mifepristone-induced PCO syndrome model in rats is appropriate in some aspects to simulate the PCO syndrome condition of ovaries in humans, because not only ovarian histology but also the hormone levels were quite similar to those of humans (Sanchez-Criado et al. 1992, 1993, Ruiz et al. 1996, 1997). Although these studies showed that the mifepristone-induced PCO syndrome model was reversible during the experimental course (Singh 2005), the PCO syndrome model is useful for histopathological studies on the mechanism of chronic anovulation and vascular functions in greater detail, considering the recent technical development of transgenic animals. An assessment of hormonal changes such as hyperandrogenism would be essential to further clarify the similarity between the mouse PCO model used in the present study and the human PCO syndrome.

In the present study, the relative volume and diameter of blood vessels in both the medulla and theca interna were significantly increased in the ovaries of the PCO model mice. Morphological changes in the blood vessels under different hemodynamic conditions are already reported to be captured in the living animal organs by the IVCT (Li et al. 2005, Ohno et al. 2006). Therefore, the present findings represent the higher ovarian blood flow in the PCO model mice. Indeed, they are consistent with the physiological data published previously, as measured by color and pulsed Doppler ultrasonography (Zaidi et al. 1995, Pan et al. 2002). In the previous studies, several growth factors were implicated in the angiogenesis and maintenance of blood flow within the living animal ovary, including basic fibroblast growth factor, transforming growth factor- $\beta$, luteinizing hormone, platelet-derived growth factor, and vascular endothelial growth factor A (VEGFA; Gospodarowicz 1974, Findlay 1986, Klagsbrun 1991, Chegini \& Flanders 1992, Folkman \& Shing 1992, Van Blerkom et al. 1997). Some physiological evidence has demonstrated a positive correlation between VEGFA and ovarian stromal blood flow velocities in PCO syndrome women (Agrawal et al. 1998a, 1998b). The increase in blood flow in both the ovarian cortex and medulla of the PCO model mice might be associated with stromal hyperplasia and excessive follicular development due to anovulation, considering the total volume expansion and cellular proliferation of the ovaries (Hughesdon 1982). Further molecular and functional studies are essential to reveal the precise significance of blood flow increase in the $\mathrm{PCO}$, and detect other undetermined factors affecting the vascularity of $\mathrm{PCO}$ ovaries.

As shown in Figs 3 and 5, the immunoreactivity of plasma proteins was clearly detected in the living mouse ovaries of the PCO model, as prepared by IVCT, which

Table 1 Semi-quantitative comparison of IgG1 immunoreactivity in different areas of ovaries.

\begin{tabular}{lrrrr}
\hline & - & + & $\mathbf{2 +}$ & $\mathbf{3 +}$ \\
\hline Vessels & & & & \\
PCO & 0 & 0 & 0 & 20 \\
$\quad$ Normal & 0 & 0 & 0 & 20 \\
Granulosa* & 16 & 4 & 0 & 0 \\
$\quad$ PCO & 0 & 8 & 12 & 0 \\
$\quad$ Normal & 0 & 10 & 10 & 0 \\
Antrum & 0 & 7 & 10 & 3 \\
$\quad$ PCO & 0 & & \\
Normal & 0 &
\end{tabular}

PCO, polycystic ovary model mice; normal, normal mice; vessels, blood vessels; granulosa, granulosa cell layer; - , negative; + , weakly positive; $2+$, moderately positive; $3+$, strongly positive; ${ }^{*} P<0.05$. 

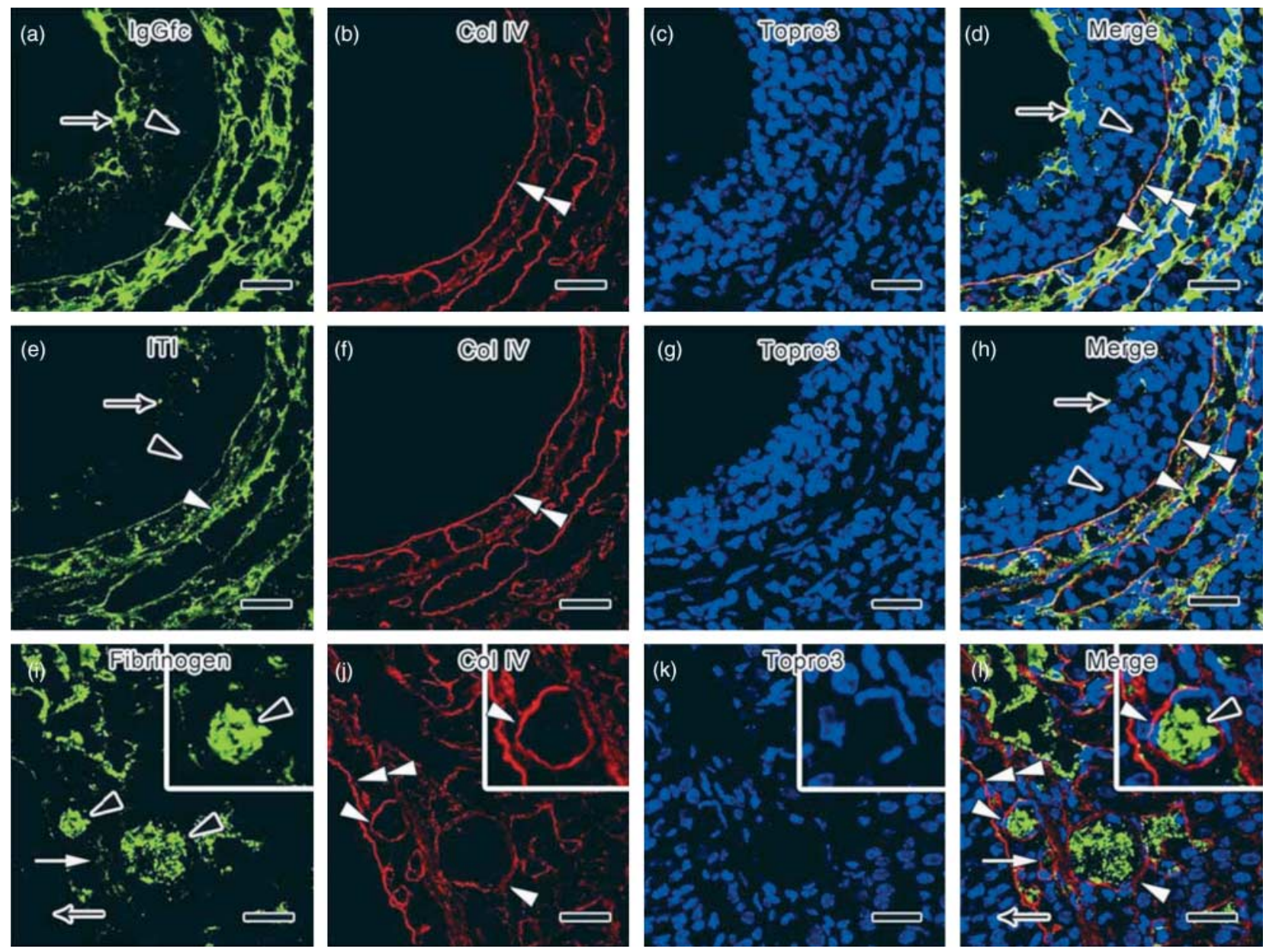

Figure 5 Double immunofluorescence micrographs of collagen type IV (Col IV; b, d, f, h, j, I; red) and immunoglobulin Gfc (IgGfc; a, d; green), inter$\alpha$-trypsin inhibitor (ITI; e, h; green) or fibrinogen (i, l; green) which are localized in the living mouse ovaries. The cellular nuclei are labeled with Topro3 (c, d, g, h, k, l; blue). (a-d) Immunoreactivity of IgGfc in antral follicles of PCO mice is almost similar to that observed in Fig. 3g; little immunoreactivity of IgGfc (a, d, black arrowheads) is seen in the granulosa cell layer of the follicles, in comparison with the thecal layers and blood vessels ( $a, d$, white arrowheads), although some immunoreactivity is detected in the antrum (a, $d$, arrows) of the PCO mice. The decrease in IgGfC immunoreactivity is clearly bordered by the follicular basement membranes immunopositive for Col IV (b, $d$, double white arrowheads). (e-h) Almost no immunoreactivity of ITI (e, h, black arrowheads) is seen in the granular cell layer in the follicles, in comparison with both the thecal layers and blood vessels (e, $h$, white arrowheads), but little immunoreactivity is seen in the antrum (e, $h$, arrows) of PCO mice. The immunolocalization of ITI is also restricted at Col IV-immunopositive basement membranes of the PCO (f, h, double white arrowheads). (i- I) The immunoreactivity of fibrinogen is more clearly seen in the blood vessels of the thecal layers (i, I, arrowheads), while it is not detected inside the antral follicles (i, I, arrows). It is mostly surrounded by vascular basement membranes immunopositive for Col IV (j, I, white arrowheads), and also partly separated at the follicular basement membranes (j, l, double white arrowheads). Bars, $20 \mu \mathrm{m}$.

could prevent various technical artifacts caused by the conventional preparation methods (Li et al. 2005, Ohno et al. 2006, Zhou et al. 2007a). A number of biochemical and morphological studies have already reported the existence of BFB in the living animal ovaries. However, the present study is the first report that the in vivo permeability of BFB against endogenous plasma proteins with different molecular sizes are immunohistochemically demonstrated in the PCO model, which also clarified the histological structures responsible for the actual barrier functions of BFB.

As shown in Fig. 7, the immunodistribution of some plasma proteins with small and large molecular weights, such as albumin and IgM, in the PCO model mice are quite similar to those in the normal mice (Zhou et al. 2007 b), but the immunoreactivity of proteins with intermediate molecular weights, such as IgG, ITI, and fibrinogen, appears to decrease inside the follicles of the PCO model mice. These findings suggest that BFB of the living mouse ovaries would have less selective functions against permeation of plasma proteins with small molecular weights, but enhanced such functions especially against those with intermediate molecular weights in PCO. In our preliminary results, the similar change in IgG immunoreactivity was observed in the rat PCO syndrome model induced by mifepristone (data not shown). The reduced passage of middle-sized plasma proteins into the antral follicles might partly result from the potential changes in 
Control
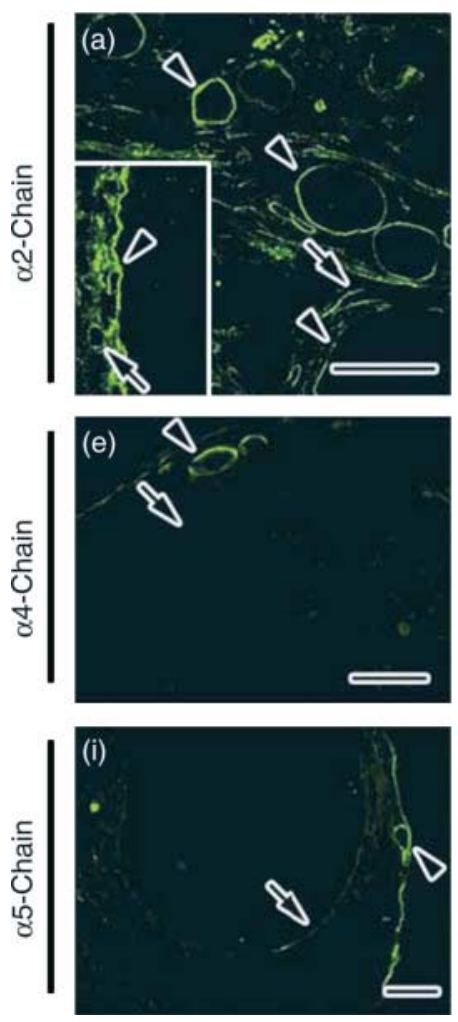
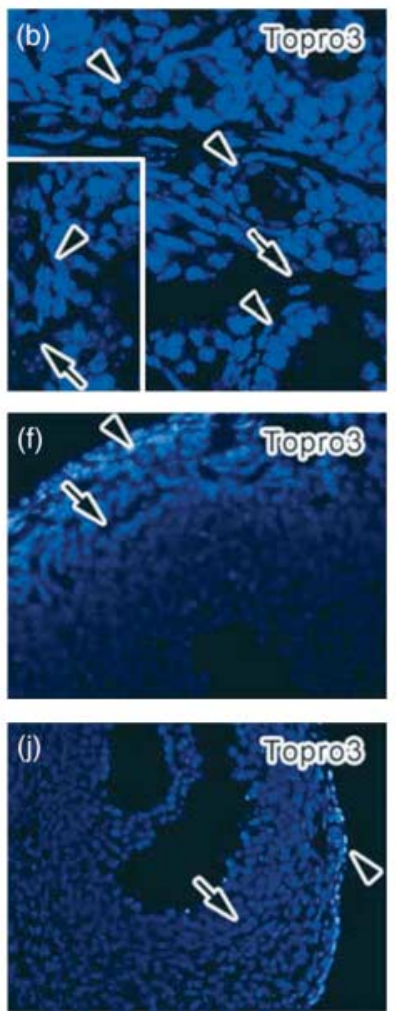

$\mathrm{PCO}$
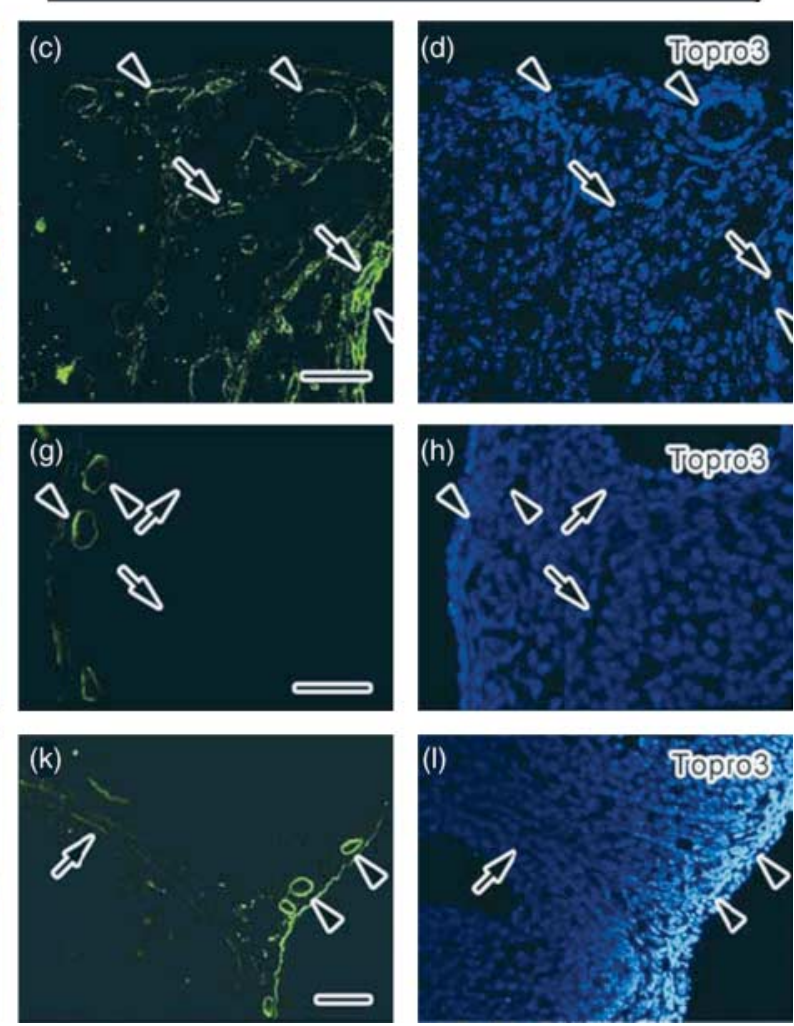

Figure 6 Immunofluorescence micrographs of collagen type IV $\alpha 2-, \alpha 4$ - and $\alpha 5$-chains in the control (N) or polycystic ovary model (PCO) mouse ovaries. The immunoreactivity of all $\alpha 2-, \alpha 4$ - and $\alpha 5$-chains in normal and PCO mice appears to be similar. The $\alpha 2$ clearly localizes in vascular (a-d, arrows) and follicular (a-d, arrowheads) basement membranes, and $\alpha 4$ is detected in the follicular basement membranes of primordial follicles (e-h, arrowheads), but not in those of antral follicles (e- $\mathrm{h}$, arrows). The $\alpha 5$ is strongly detected in the follicular basement membranes of primordial follicles (i-l, arrowheads) and weakly detected in those of the antral follicles (i-l, arrows). Bars, $50 \mu \mathrm{m}$.

the extracellular matrix components around the developing follicles, because appropriately remodeled extracellular matrices are required for normal physiological ovulation, which is usually disturbed in the PCO syndrome ovaries (Goldman \& Shalev 2004, Oksjoki et al. 2004, Curry \& Smith 2006). Although it was also reported that only a fraction of ITI was bound to hyaluronic acid (Odum et al. 2001), the reduction in follicular ITI, which binds to intrafollicular hyaluronic acid produced by granulosa cells and thus stabilizes the cumulus extracellular matrix, may also be partly responsible for the disturbance of appropriate follicular expansion and ovulation (Chen et al. 1994, Hess et al. 1999).

On the other hand, the immunoreactivity of fibrinogen $(340 \mathrm{kDa})$ appeared to be bordered at the vascular endothelial cells surrounded by collagen type IV-immunopositive basement membranes (Figs 5 and $7 \mathrm{~b}$ ), although it passed through the basement membranes into the interstitium in normal mouse ovaries under physiological conditions (Fig. 7a; Zhou et al. 2007b). The endothelial cells were assumed to be one of the important sites for the BFB with the stricter permselectivity in the PCO syndrome than that in normal animal ovaries (Powers et al. 1995, Zhou et al. 2007b). Morphological changes during follicular development always depend on dynamic cellular rearrangements in the living animal ovaries, partly regulated by cell-cell adhesion molecules (Bazzoni \& Dejana 2004, Walz et al. 2005). One of the major intercellular junctions is the tight junction, which is the most apical junction of epithelial and endothelial cells completely sealing their intercellular spaces, and occludin and claudins are the major molecules of the tight junctions (Dejana 2004, Schneeberger \& Lynch 2004). In a previous report, the systemic VEGFA inhibition resulted in the down-regulation of claudin 5 in the endothelium of the thecal vasculature of ovaries (Rodewald et al. 2007). If the ovarian blood flow and VEGFA expression in blood circulation significantly increase in the PCO syndrome (Agrawal et al. 1998a, 1998b), the enhanced permselectivity of endothelial cells would thus be mediated by the up-regulation of claudin.

Besides the endothelial cells functioning in BFB, the present findings also suggest that basement membranes of developing follicles to play some important roles in the functional changes in BFB permselectivity, as shown in Fig. 7. Although the structural components of basement membranes can severely affect their permselectivity (Hudson et al. 1993, Noakes et al. 1995), the 
(a)
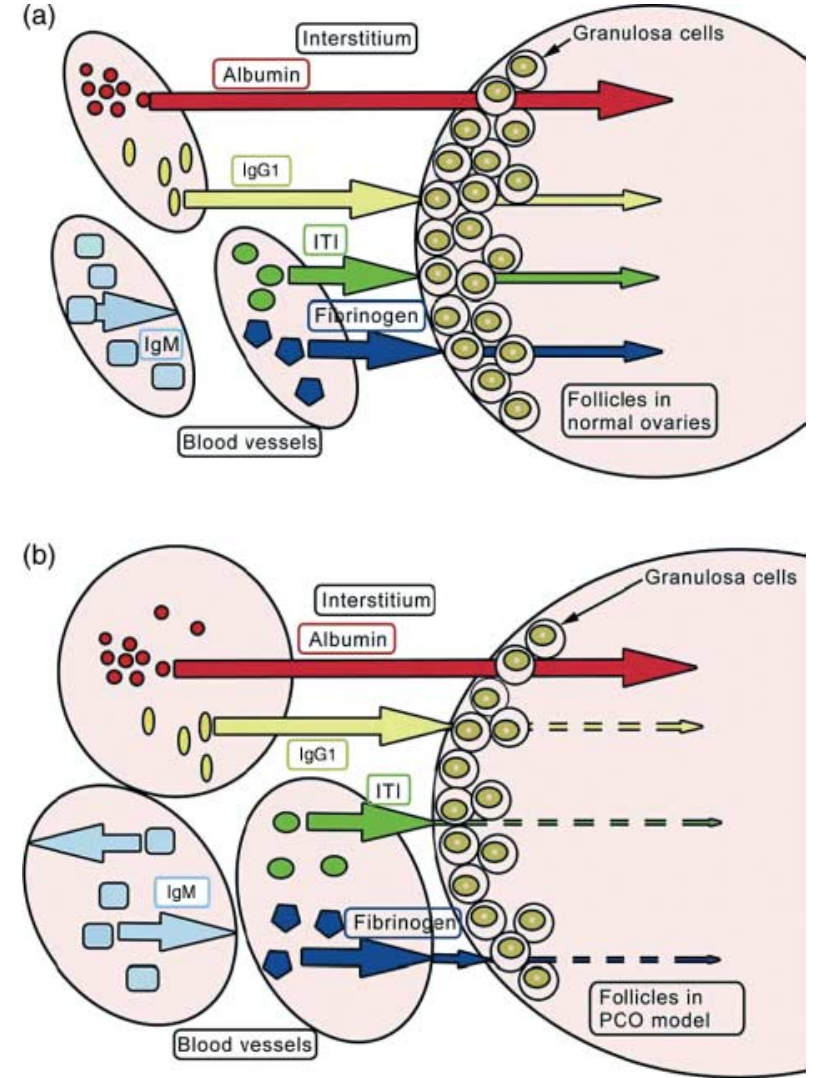

Figure 7 Schematic of plasma protein distribution summarized in normal (a) or polycystic ovary model (PCO; b) mice. The relative thickness of each arrow corresponds to the immunoreactive intensity of each molecule. In both normal and PCO model mice, albumin (69 kDa, red) is immunolocalized in blood vessels, interstitium and antral follicles, and immunoglobulin M (IgM, $900 \mathrm{kDa}$; light blue) is mostly restricted within blood vessels. In contrast, the immunodistribution of some plasma proteins with intermediate molecular weights were different between normal and PCO mice. Immunoreactivity of IgG1 (150 kDa; yellow) and inter- $\alpha$-trypsin inhibitor (ITI, 220 kDa; green) is hardly detected in the membrana granulose, and appear to be bordered at the follicular basement membranes. The immunoreactivity of fibrinogen (340 kDa; blue) is decreased in the interstitium, in comparison with inside of blood vessels, and also bordered by endothelial cells in the PCO mice.

immunoreactivity of collagen type IV $\alpha 2-, \alpha 4-$ and $\alpha 5-$ chains in the follicular basement membranes was not significantly different between the PCO model and control mice. In addition, few ultrastructural changes in follicular basement membranes have been reported in the PCO syndrome (Irving-Rodgers \& Rodgers 2005). However, further molecular analyses on other components of basement membranes, such as laminins, perlecan, and nidogens, would be essential to reveal their possible involvement in the permselectivity of the BFB (Irving-Rodgers \& Rodgers 2006). Ultrastructural analyses of the follicular basement membranes, which are prepared with IVCT or quick freezing followed by deep-etch replication, would also have a significant meaning at a molecular level, because the conventional preparation methods are reported to cause some shrinkage artifacts of basement membranes at an ultrastructural level (Chan \& Inoue 1994). In addition, the reversibility of the changes observed in the present mouse study should also be further examined in another experiment, given that the changes in a mifepristone-induced PCO syndrome model have been reported to be reversible in rats (Singh 2005).

In conclusion, enlarged blood vessels with abundant blood flow had been observed in the ovaries of the PCO model mice prepared with IVCT, in addition to the formation of follicular cysts with the degenerative membrana granulosa. Furthermore, although the immunolocalization of plasma proteins with low and high molecular weights, such as albumin and IgM, in the PCO model mice were similar to those in normal mice, other plasma proteins with intermediate molecular weights, such as IgG1, ITI, and fibrinogen, appeared to be bordered more strictly at the BFB in the PCO model mice. These findings suggest that the increased ovarian blood flow and enhanced selectivity of molecular permeation through the BFB are functional features in the PCO model ovaries, and such changes in hemodynamic conditions and permselectivity of BFB therefore play a significant role in the pathogenesis and pathophysiology of PCO syndrome.

\section{Materials and Methods}

\section{Animals and experimental design}

Female $\mathrm{C} 57 \mathrm{BL} / 6$ mice aged 8 weeks were bred and housed locally at $22{ }^{\circ} \mathrm{C}$ under a $14 \mathrm{~h}$ light: $10 \mathrm{~h}$ darkness cycle, with free access to food and water. Mice showing at least two consecutive 4-5 days estrous cycles were used, as assessed daily by vaginal smear examination. All animal experiments were performed in accordance with the guidelines by the Animal Care and Use Committee, University of Yamanashi. The progesterone antagonist mifepristone was purchased from Cayman Chemical (Ann Arbor, MI, USA).

The treatment group comprised 12 mice subcutaneously injected daily with mifepristone in olive oil $(4 \mathrm{mg} / 0.2 \mathrm{ml}$ olive oil/100 g body weight/day), beginning on day 1 of the estrous cycle. Six control mice were injected with olive oil alone ( $0.2 \mathrm{ml}$ olive oil/100 g body weight/day). After 9 days of the injection, ovarian tissues of these mice, which were anesthetized with inhalation of diethyl ether, were prepared by the following different methods.

\section{Tissue preparation methods}

(i) PF-DH: two PCO model mice and two control mice were transcardially perfused with $2 \%$ paraformaldehyde in 0.1 M phosphate buffer (pH 7.4), and their ovarian tissues were resected and immersed in the same fixative overnight.

(ii) IVCT: the isopentane-propane cryogen was poured over the carefully exposed ovaries of ten PCO model mice and four control mice, as reported previously (Ohno et al. 2006), and then the completely frozen tissues were removed with a dental electric drill in liquid nitrogen $\left(-196^{\circ} \mathrm{C}\right)$. 
All the specimens prepared by (i) were dehydrated with a graded series of ethanol, and those by (ii) were routinely freeze-substituted with acetone containing $2 \%$ paraformaldehyde and embedded in either paraffin wax or OCT compound, as described previously (Ohno et al. 2004, Terada et al. 2005).

\section{Immunohistochemistry of plasma proteins}

All paraffin-embedded samples were cut at $3 \mu \mathrm{m}$ thickness and mounted on glass slides treated with 3-aminopropyltriethoxysilane (Nacalai Tesque, Kyoto, Japan). The thin sections were then deparaffinized with xylene and a graded series of ethanol. For histological analyses, some serial sections were routinely stained with HE. For immunohistochemical analyses, others were incubated with $1 \%$ hydrogen peroxide in PBS for $1 \mathrm{~h}$ and then $5 \%$ normal rabbit serum in PBS for $1 \mathrm{~h}$. They were immunostained with various primary antibodies in PBS containing $5 \%$ normal rabbit serum at $4{ }^{\circ} \mathrm{C}$ overnight. The primary antibodies were goat anti-mouse albumin antibody at a dilution of 1:5000, goat anti-mouse IgG1 antibody at a dilution of 1:500, and goat anti-mouse $\lg M$ antibody at a dilution of 1:500. They were all purchased from Bethyl Laboratories (Montgomery, TX, USA). The immunocontrol was prepared by incubating the sections in $5 \%$ normal rabbit serum without the primary antibodies. The immunostained sections were then incubated in biotin-conjugated rabbit anti-goat IgG (Vector Laboratories, Burlingame, CA, USA) at a dilution of 1:200 at room temperature for $1 \mathrm{~h}$. The immunoreaction products were visualized with Vectastain $A B C$ reagent (Vector Laboratories) and metal-enhanced diaminobenzidine substrate kit (Pierce, Rockford, IL, USA), and additionally fixed with $0.04 \%$ osmium tetroxide solution as described previously (Ohno et al. 2005). All immunostained sections were counterstained with methyl green, embedded in glycerol, and observed with a light microscope (BX-61; Olympus, Tokyo, Japan).

For double immunofluorescence labeling, cryosections at $6 \mu \mathrm{m}$ thickness and also deparaffinized sections on the glass slides were blocked with 2\% gelatin (Sigma) in PBS for $1 \mathrm{~h}$ and immunostained with the primary antibodies at $4{ }^{\circ} \mathrm{C}$ overnight as follows: i) rabbit anti-human fibrinogen antibody (Dako Japan, Kyoto, Japan) at a dilution of 1:500, ii) rabbit anti-mouse IgGfC antibody (Bethyl Laboratories) at a dilution of 1:500, iii) rabbit anti-human ITI antibody (Dako) at a dilution of 1:400, iv) goat anti-mouse type IV collagen antibody (Southern Biotechnology Associates, Birmingham, AL, USA) at a dilution of 1:50, and v) rat anti-human type IV collagen $\alpha 2-, \alpha 4$ - and $\alpha 5$ chain antibodies cross-reacting to each mouse type IV collagen $\alpha$-chain at a dilution of 1:5 (Sado et al. 1995, Saito et al. 2000). They were then incubated with donkey anti-rabbit and anti-rat $\operatorname{lgG}$ antibodies coupled to Alexa Fluor 488 at a dilution of 1:400, donkey anti-goat $\lg G$ antibody coupled to Alexa Fluor 546 at a dilution of 1:400, and Topro3 at a dilution of 1:500 (Invitrogen), with $2 \%$ gelatin in PBS at room temperature for $1 \mathrm{~h}$. The immunostained cryosections were embedded in Vectashield (Vector Laboratories), and observed with a confocal laser scanning microscope (FV1000; Olympus).

\section{Quantitative analyses}

The number of antral follicles was counted on each section stained with HE. For these sections, two to three ovarian sections were selected from $\sim 60$ serial ovarian sections of each animal in either PCO model or normal mouse group. The sections of normal mouse ovaries at the stage of proestrous to estrous were obtained from the previous study (Zhou et al. 2007b). To calculate the thickness ratio, antral follicles were identified on the ovarian sections, and in each follicle, the smallest thickness of the granulosa cell layer was measured. Thereafter, the thickness of granulosa cell layer was divided by the thickness of the adjacent thecal cell layer. A total of 20 follicles were selected from eight mice in each of PCO model and the normal groups. For comparison of blood vessel volume, the modified Chalkley counting procedure, in which the relative volume of certain profiles are estimated on histological sections with a 25-point Chalkley eyepiece graticule, was used (Chalkley 1943, Curtis 1960). Briefly, three areas in the ovarian medulla with the highest number of microvessel profiles were chosen subjectively from each ovary section. The Chalkley $0.196 \mathrm{~mm}^{2}$ sized grid was superimposed on the areas and rotated until the maximal number of dots on the grid hits highlighted blood vessel profiles with flowing erythrocytes, and then the number of dots was counted on the blood vessel profiles. The Chalkley count for each section was taken as the mean value of the three graticule counts. A total of five Chalkley counts for each sample were obtained, based on five different sections. The length of the shorter axis of each blood vessel profile was also measured on digital images of HE-stained sections by evaluating 50 blood vessels.

For the semi-quantitative analysis of IgG1 immunoreactivity, 20 follicles on sections immunostained for lgG1 were selected from eight mice in each of the PCO model and normal groups. Thereafter, the immunoreactivity in thecal blood vessels, granulosa cell layer and antrum of each follicle was classified into four categories, which were negative $(-)$, weakly positive $(+)$, moderately positive $(2+)$, and strongly positive $(3+)$, with the naked eye under a light microscope.

The number of antral follicles, thickness ratio, data obtained by the modified Chalkley method, and semi-quantitative data of IgG1 immunoreactivity were statistically analyzed by the non-parametric Kruskal-Wallis H-test using SPSS 11.5 software for Windows (SPSS Inc., Chicago, IL, USA). The data of blood vessel diameters were analyzed by Student's $t$-test using the SPSS 11.5 software for windows. $P<0.05$ was considered to be significant.

\section{Declaration of interest}

The authors declare no conflict of interest that could be perceived as prejudicing the impartiality of the research reported.

\section{Funding}

This research did not receive any specific grant from any funding agency in the public, commercial or not-for-profit sector. 


\section{References}

Agrawal R, Conway G, Sladkevicius P, Tan SL, Engmann L, Payne N, Bekir J, Campbell S \& Jacobs H 1998a Serum vascular endothelial growth factor and Doppler blood flow velocities in in vitro fertilization: relevance to ovarian hyperstimulation syndrome and polycystic ovaries. Fertility and Sterility 70 651-658.

Agrawal R, Sladkevicius P, Engmann L, Conway GS, Payne NN, Bekis J, Tan SL, Campbell S \& Jacobs HS 1998b Serum vascular endothelial growth factor concentrations and ovarian stromal blood flow are increased in women with polycystic ovaries. Human Reproduction 13 651-655.

Angelucci S, Ciavardelli D, Di Giuseppe F, Eleuterio E, Sulpizio M, Tiboni GM, Giampietro F, Palumbo P \& Di Ilio C 2006 Proteome analysis of human follicular fluid. Biochimica et Biophysica Acta 1764 1775-1785.

Bazzoni G \& Dejana E 2004 Endothelial cell-to-cell junctions: molecular organization and role in vascular homeostasis. Physiological Reviews $\mathbf{8 4}$ 869-901.

Van Blerkom J, Antczak M \& Schrader R 1997 The developmental potential of the human oocyte is related to the dissolved oxygen content of follicular fluid: association with vascular endothelial growth factor levels and perifollicular blood flow characteristics. Human Reproduction 12 1047-1055.

Chalkley HW 1943 Method for the quantitative morphologic analysis of tissues. Journal of the National Cancer Institute 4 47-53.

Chan FL \& Inoue S 1994 Lamina lucida of basement membrane: an artefact. Microscopy Research and Technique 28 48-59.

Chegini N \& Flanders KC 1992 Presence of transforming growth factor- $\beta$ and their selective cellular localization in human ovarian tissue of various reproductive stages. Endocrinology 130 1707-1715.

Chen L, Mao SJ, McLean LR, Powers RW \& Larsen WJ 1994 Proteins of the inter-alpha-trypsin inhibitor family stabilize the cumulus extracellular matrix through their direct binding with hyaluronic acid. Journal of Biological Chemistry 269 28282-28287.

Cran DG, Moor RM \& Hay MF 1976 Permeability of ovarian follicles to electron-dense macromolecules. Acta Endocrinologica 82 631-636.

Curry TE Jr \& Smith MF 2006 Impact of extracellular matrix remodeling on ovulation and the folliculo-luteal transition. Seminars in Reproductive Medicine 24 228-241.

Curtis AS 1960 Area and volume measurements by random sampling methods. Medical and Biological Illustration 10 261-266.

Dejana E 2004 Endothelial cell-cell junctions: happy together. Nature Reviews. Molecular Cell Biology 5 261-270.

Donahue RP \& Stern S 1968 Follicular cell support of oocyte maturation: production of pyruvate in vitro. Journal of Reproduction and Fertility 17 395-398.

Ehrmann DA 2005 Polycystic ovary syndrome. New England Journal of Medicine 352 1223-1236.

Findlay JK 1986 Angiogenesis in reproductive tissues. Journal of Endocrinology $111357-366$.

Folkman J \& Shing Y 1992 Angiogenesis. Journal of Biological Chemistry 267 10931-10934.

Franks S 1989 Polycystic ovary syndrome: a changing perspective. Clinical Endocrinology 31 87-120.

Franks S 1995 Polycystic ovary syndrome. New England Journal of Medicine 333 853-861.

Gao Y \& Short RV 1994 Fertility control in laboratory rats and mice after feeding with the antigestagen RU486. Journal of Reproduction and Fertility 101 477-481.

Goldman S \& Shalev E 2004 MMPS and TIMPS in ovarian physiology and pathophysiology. Frontiers in Bioscience 9 2474-2483.

Gosden RG, Hunter RH, Telfer E, Torrance C \& Brown N 1988 Physiological factors underlying the formation of ovarian follicular fluid. Journal of Reproduction and Fertility 82 813-825.

Gospodarowicz D 1974 Localisation of a fibroblast growth factor and its effect alone and with hydrocortisone on 3T3 cell growth. Nature $\mathbf{2 4 9}$ 123-127.

Gull I, Geva E, Lerner-Geva L, Lessing JB, Wolman I \& Amit A 1999 Anaerobic glycolysis. The metabolism of the preovulatory human oocyte. European Journal of Obstetrics, Gynecology, and Reproductive Biology 85 225-228.
Hansen S, Sorensen FB, Vach W, Grabau DA, Bak M \& Rose C 2004 Microvessel density compared with the Chalkley count in a prognostic study of angiogenesis in breast cancer patients. Histopathology $\mathbf{4 4}$ 428-436.

Hess KA, Chen L \& Larsen WJ 1999 Inter-alpha-inhibitor binding to hyaluronan in the cumulus extracellular matrix is required for optimal ovulation and development of mouse oocytes. Biology of Reproduction 61 436-443.

Hippe-Sanwald S 1993 Impact of freeze substitution on biological electron microscopy. Microscopy Research and Technique 24 400-422.

Hudson BG, Reeders ST \& Tryggvason K 1993 Type IV collagen: structure, gene organization, and role in human diseases. Molecular basis of Goodpasture and Alport syndromes and diffuse leiomyomatosis. Journal of Biological Chemistry 268 26033-26036.

Hughesdon PE 1982 Morphology and morphogenesis of the Stein-Leventhal ovary and of so-called 'hyperthecosis'. Obstetrical and Gynecological Survey 37 59-77.

Irving-Rodgers HF \& Rodgers RJ 2005 Extracellular matrix in ovarian follicular development and disease. Cell and Tissue Research 322 89-98.

Irving-Rodgers HF \& Rodgers RJ 2006 Extracellular matrix of the developing ovarian follicle. Seminars in Reproductive Medicine $\mathbf{2 4}$ 195-203.

Kellenberger E 1991 The potential of cryofixation and freeze substitution: observations and theoretical considerations. Journal of Microscopy 161 183-203.

Klagsbrun M 1991 Regulators of angiogenesis: stimulators, inhibitors, and extracellular matrix. Journal of Cellular Biochemistry 47 199-200.

Knochenhauer ES, Key TJ, Kahsar-Miller M, Waggoner W, Boots LR \& Azziz R 1998 Prevalence of the polycystic ovary syndrome in unselected black and white women of the southeastern United States: a prospective study. Journal of Clinical Endocrinology and Metabolism 83 3078-3082.

Lakhani K, Yang W, Dooley A, El-Mahdi E, Sundaresan M, McLellan S, Bruckdorfer R, Leonard A, Seifalian A \& Hardiman P 2006 Aortic function is compromised in a rat model of polycystic ovary syndrome. Human Reproduction 21 651-656.

Legro RS 2001 Polycystic ovary syndrome: the new millenium. Molecular and Cellular Endocrinology 184 87-93.

Li Z, Terada N, Ohno N \& Ohno S 2005 Immunohistochemical analyses on albumin and immunoglobulin in acute hypertensive mouse kidneys by 'in vivo cryotechnique'. Histology and Histopathology 20 807-816.

Li Z, Ohno N, Terada N \& Ohno S 2006 Immunolocalization of serum proteins in living mouse glomeruli under various hemodynamic conditions by 'in vivo cryotechnique'. Histochemistry and Cell Biology 126 399-406.

Liao X, Terada N, Ohno N, Li Z, Fujii Y, Baba T \& Ohno S 2006 Immunohistochemical study of serum albumin in normal and cadmiumtreated mouse testis organs by 'in vivo cryotechnique'. Histology and Histopathology 21 35-40.

Loutradis D, Bletsa R, Aravantinos L, Kallianidis K, Michalas S \& Psychoyos A 1991 Preovulatory effects of the progesterone antagonist mifepristone (RU486) in mice. Human Reproduction 6 1238-1240.

Mahajan DK 1988 Polycystic ovarian disease: animal models. Endocrinology and Metabolism Clinics of North America 17 705-732.

Mahesh VB, Mills TM, Bagnell CA \& Conway BA 1987 Animal models for study of polycystic ovaries and ovarian atresia. Advances in Experimental Medicine and Biology 219 237-257.

Nakano K, Naito I, Momota R, Sado Y, Hasegawa H, Ninomiya Y \& Ohtsuka A 2007 Distribution of type IV collagen $\alpha$ chains in the mouse ovary and its co-relation to follicular development. Archives of Histology and Cytology $70243-253$.

Noakes PG, Miner JH, Gautam M, Cunningham JM, Sanes JR \& Merlie JP 1995 The renal glomerulus of mice lacking s-laminin/laminin beta 2: nephrosis despite molecular compensation by laminin $\beta 1$. Nature Genetics 10 400-406.

Odum L, Jessen TE \& Andersen CY 2001 Glycosaminoglycan-bound and free inter- $\alpha$-trypsin inhibitor components of follicular fluid. Zygote $\mathbf{9}$ 283-288.

Ohno N, Terada N \& Ohno S 2004 Advanced application of the in vivo cryotechnique to immunohistochemistry for animal organs. Acta Histochemica et Cytochemica 37 357-364. 
Ohno N, Terada N, Tanaka J, Yokoyama A, Yamakawa H, Fujii Y, Baba T, Ohara O \& Ohno S 2005 Protein $4.1 \mathrm{G}$ localizes in rodent microglia. Histochemistry and Cell Biology 124 477-486.

Ohno N, Terada N \& Ohno S 2006 Histochemical analyses of living mouse liver under different hemodynamic conditions by 'in vivo cryotechnique'. Histochemistry and Cell Biology 126 389-398.

Oksjoki S, Rahkonen O, Haarala M, Vuorio E \& Anttila L 2004 Differences in connective tissue gene expression between normally functioning, polycystic and post-menopausal ovaries. Molecular Human Reproduction $107-14$.

Onalan G, Selam B, Baran Y, Cincik M, Onalan R, Gunduz U, Ural AU \& Pabuccu R 2005 Serum and follicular fluid levels of soluble Fas, soluble Fas ligand and apoptosis of luteinized granulosa cells in PCOS patients undergoing IVF. Human Reproduction 20 2391-2395.

Pan HA, Wu MH, Cheng YC, Li CH \& Chang FM 2002 Quantification of Doppler signal in polycystic ovary syndrome using three-dimensional power Doppler ultrasonography: a possible new marker for diagnosis. Human Reproduction 17 201-206.

Powers RW, Chen L, Russell PT \& Larsen WJ 1995 Gonadotropin-stimulated regulation of blood-follicle barrier is mediated by nitric oxide. American Journal of Physiology 269 E290-E298.

Rodewald M, Herr D, Fraser HM, Hack G, Kreienberg R \& Wulff C 2007 Regulation of tight junction proteins occludin and claudin 5 in the primate ovary during the ovulatory cycle and after inhibition of vascular endothelial growth factor. Molecular Human Reproduction 13 781-789.

Rodgers HF, Irvine CM, van Wezel IL, Lavranos TC, Luck MR, Sado Y, Ninomiya Y \& Rodgers RJ 1998 Distribution of the alpha1 to alpha6 chains of type IV collagen in bovine follicles. Biology of Reproduction $\mathbf{5 9}$ 1334-1341.

Ruiz A, Aguilar R, Tebar AM, Gaytan F \& Sanchez-Criado JE 1996 RU486treated rats show endocrine and morphological responses to therapies analogous to responses of women with polycystic ovary syndrome treated with similar therapies. Biology of Reproduction 55 1284-1291.

Ruiz A, Tebar M, Perez-Romero A, Rol de Lama MA \& Sanchez-Criado JE 1997 Serum levels of GH, IGF-I, LH and ovarian steroids in cyclic and RU486-treated rats. Journal of Endocrinological Investigation 20 611-615.

Sado Y, Kagawa M, Kishiro Y, Sugihara K, Naito I, Seyer JM, Sugimoto M, Oohashi T \& Ninomiya Y 1995 Establishment by the rat lymph node method of epitope-defined monoclonal antibodies recognizing the six different alpha chains of human type IV collagen. Histochemistry and Cell Biology 104 267-275.

Saito K, Naito I, Seki T, Oohashi T, Kimura E, Momota R, Kishiro Y, Sado Y, Yoshioka H \& Ninomiya Y 2000 Differential expression of mouse $\alpha 5$ (IV) and $\alpha 6(\mathrm{IV})$ collagen genes in epithelial basement membranes. Journal of Biochemistry 128 427-434.

Sanchez-Criado JE, Bellido C, Lopez FJ \& Galiot F 1992 Antiprogesterone RU486 induces dissociation of $\mathrm{LH}$ and FSH secretion in the cyclic rat: effect of anti-inhibin serum. Journal of Endocrinology 134 43-49.

Sanchez-Criado JE, Tebar M, Sanchez A \& Gaytan F 1993 Evidence that androgens are involved in atresia and anovulation induced by antiprogesterone RU486 in rats. Journal of Reproduction and Fertility 99 173-179.

San Roman GA \& Magoffin DA 1992 Insulin-like growth factor binding proteins in ovarian follicles from women with polycystic ovarian disease: cellular source and levels in follicular fluid. Journal of Clinical Endocrinology and Metabolism 75 1010-1016.
Schneeberger EE \& Lynch RD 2004 The tight junction: a multifunctional complex. American Journal of Physiology. Cell Physiology 286 C1213-C1228.

Shalgi R, Kraicer P, Rimon A, Pinto M \& Soferman N 1973 Proteins of human follicular fluid: the blood-follicle barrier. Fertility and Sterility $\mathbf{2 4}$ 429-434.

Shiurba R 2001 Freeze-substitution: origins and applications. International Review of Cytology 206 45-96.

Singh KB 2005 Persistent estrus rat models of polycystic ovary disease: an update. Fertility and Sterility 84 (Supplement 2) 1228-1234.

Szukiewicz D \& Uilenbroek JT 1998 Polycystic ovary syndrome - searching for an animal model. Journal of Medicine 29 259-275.

Terada N, Ohno N, Li Z, Fujii Y, Baba T \& Ohno S 2005 Detection of injected fluorescence-conjugated $\lg G$ in living mouse organs using 'in vivo cryotechnique' with freeze-substitution. Microscopy Research and Technique 66 173-178.

The Rotterdam ESHRE/ASRM-Sponsored PCOS Consensus Workshop Group 2004 Revised 2003 consensus on diagnostic criteria and longterm health risks related to polycystic ovary syndrome (PCOS). Human Reproduction 19 41-47.

Walz A, Keck C, Weber H, Kissel C \& Pietrowski D 2005 Effects of luteinizing hormone and human chorionic gonadotropin on corpus luteum cells in a spheroid cell culture system. Molecular Reproduction and Development 72 98-104.

Welt CK, Taylor AE, Fox J, Messerlian GM, Adams JM \& Schneyer AL 2005 Follicular arrest in polycystic ovary syndrome is associated with deficient inhibin A and B biosynthesis. Journal of Clinical Endocrinology and Metabolism 90 5582-5587.

Williams CS, Leek RD, Robson AM, Banerji S, Prevo R, Harris AL \& Jackson DG 2003 Absence of lymphangiogenesis and intratumoural lymph vessels in human metastatic breast cancer. Journal of Pathology 200 195-206.

Zachariae $\mathbf{F} 1958$ Studies on the mechanism of ovulation: permeability of the blood-liquor barrier. Acta Endocrinologica 27 339-342.

Zaidi J, Campbell S, Pittrof R, Kyei-Mensah A, Shaker A, Jacobs HS \& Tan SL 1995 Ovarian stromal blood flow in women with polycystic ovaries - a possible new marker for diagnosis? Human Reproduction 10 1992-1996.

Zea-Aragon Z, Terada N, Ohno N, Fujii Y, Baba T \& Ohno S 2004 Effects of anoxia on serum immunoglobulin and albumin leakage through bloodbrain barrier in mouse cerebellum as revealed by cryotechniques. Journal of Neuroscience Methods 138 89-95.

Zhou D, Ohno N, Terada N, Li Z, Morita H, Inui K, Yoshimura A \& Ohno S 2007 a Immunohistochemical analyses on serum proteins in nephrons of protein-overload mice by 'in vivo cryotechnique'. Histology and Histopathology 22 137-145.

Zhou H, Ohno N, Terada N, Saitoh S, Fujii Y \& Ohno S 2007 b Involvement of follicular basement membrane and vascular endothelium in blood follicle barrier formation of mice revealed by 'in vivo cryotechnique'. Reproduction 134 307-317.

Received 12 January 2008

First decision 15 April 2008

Revised manuscript received 1 July 2008

Accepted 21 August 2008 